\title{
METODE SPATIAL AUTOREGRESSIVE DALAM MEMODELKAN MASYARAKAT YANG BERPERILAKU MCK DI SUNGAI
}

\author{
Komang Kokom Sucahyati Dewi P. ${ }^{1 \S}$, Made Susilawati ${ }^{2}$, I Wayan Sumarjaya ${ }^{3}$ \\ ${ }^{1}$ Jurusan Matematika, Fakultas MIPA - Universitas Udayana [kokom.sucahyati@gmail.com] \\ ${ }^{2}$ Jurusan Matematika, Fakultas MIPA - Universitas Udayana [mdsusilawati@unud.ac.id] \\ ${ }^{3}$ Jurusan Matematika, Fakultas MIPA - Universitas Udayana [sumarjaya@unud.ac.id] \\ ${ }^{\S}$ Corresponding Author
}

\begin{abstract}
Spatial autoregressive (SAR) is a model of spatial regression which assumes that autoregressive process is only for the dependent variable by considering the spatial effect. The spatial effect consists of spatial dependence and spatial heterogeneity. One of problems which considers spatial effect is the case of society which do public bathing, washing, and toilets facilities (PBWTF) in the river, in Blahbatuh District. The aim of this research is to obtaine the model of society which still do PBWTF in the river, in Blahbatuh Districts in 2016 and to determine the factors that influence it. In this research, we obtained the model which is able to illustrate the case of society which do PBWTF and the factors that influence it such as the amount of householde which do not have latrine and the amount of family who lives near the river in every subvillage in Blahbatuh District.
\end{abstract}

Keywords: SAR, Spatial Effect, and Public Bathing, Washing, and Toilets Facilities in the River.

\section{PENDAHULUAN}

Spatial autoregressive (SAR) merupakan model yang menggabungkan antara model regresi linear dengan lag spasial pada variabel respon dengan menggunakan data cross section dan diasumsikan bahwa proses autoregresif hanya terjadi pada variabel respons (Anselin, 1988). SAR merupakan salah satu pemodelan spasial yang berkaitan dengan pendekatan area.

Hukum Tobler menyatakan bahwa segala sesuatu saling berhubungan dengan yang lainnya, namun sesuatu yang lebih dekat akan lebih berpengaruh dibandingkan dengan yang jauh (Anselin, 1988). SAR dapat diterapkan dalam bidang kesehatan. Salah satu upaya yang telah dilakukan Pemerintah dalam meningkatkan kesehatan masyarakat adalah mempromosikan Perilaku Hidup Bersih dan Sehat (PHBS).

Terdapat sepuluh kategori PHBS dan dua diantaranya yaitu penggunaan air bersih dan peggunaan jamban sehat belum sepenuhnya diterapkan oleh sekitar 35,62\% KK di Kecamatan Blahbatuh. Hal tersebut dapat dilihat dari adanya masyarakat yang berperilaku MCK di sungai. Penelitan Qudsiyah (2015) yang menemukan bahwa kepemilikan jamban memengaruhi angka sanitasi di Kabupaten Jember pada tahun 2015, sedangkan penelitian Sasongko (2011) menyebutkan bahwa penduduk yang tinggal dekat sungai cenderung memanfaatkan air sungai dalam memenuhi kebutuhannya.

Peneliti menduga bahwa kondisi geografis Kecamatan Blahbatuh memengaruhi masyarakat berperilaku MCK di sungai, sehingga dalam menganalisis kasus tersebut digunakan regresi spasial. Tujuan penelitian ini adalah untuk memperoleh model dari kasus masyarakat yang berperilaku MCK di sungai dengan menggunakan metode SAR dan mendeskripsikan faktor-faktor penyebab dari kasus tersebut, sehingga pemerintah mampu mengambil langkah tepat dalam mengatasi masyarakatnya yang berperilaku MCK di sungai. 


\section{METODE PENELITIAN}

\section{A. Jenis dan Sumber Data}

Data yang digunakan pada penelitian ini adalah data sekunder yang peneliti peroleh dari beberapa sumber yaitu BPS Kabupaten Gianyar Tahun 2011, Data Kependudukan per Desa Tahun 2016 yang diperoleh dari Kantor Kecamatan Blahbatuh, Puskesmas II Blahbatuh dan masing-masing Kantor Desa di Kecamatan Blahbatuh.

\section{B. Peubah Penelitian}

Penelitian ini menggunakan peubah respon yaitu jumlah KK yang berperilaku MCK di sungai di Kecamatan Blahbatuh pada tahun 2016, sedangkan peubah bebas terdiri atas empat kategori yaitu jumlah KK miskin per dusun $\left(X_{1}\right)$, jumlah $\mathrm{KK}$ yang belum memiliki jamban per dusun $\left(X_{2}\right)$, data jumlah KK tiap dusun yang tinggal dekat sungai $\left(X_{3}\right)$, dan data jarak (meter) sungai ke pemukiman terdekat untuk tiap dusunnya serta $\left(X_{4}\right)$.

\section{Metode Analisis Data}

Spatial autoregressive (SAR) merupakan kombinasi antara model regresi sederhana dengan lag spasial yang menggunakan data cross section (LeSage, 1999). Model umum SAR yaitu:

$$
\begin{aligned}
& y=\rho W_{1} y+X \beta+\varepsilon \\
& \varepsilon \sim N\left(0, \sigma^{2} \mathrm{I}\right)
\end{aligned}
$$

Langkah- langkah dalam menganalisis data pada penelitian ini adalah sebagai berikut:

a. Melakukan eksplorasi data berdasarkan peta tematik Kecamatan Blahbatuh (Gambar 1) sehingga dapat diketahui pola penyebaran data.

b. Membuat matriks pembobot spasial berdasarkan interaksi Rook Contiguity, yaitu matriks yang digunakan untuk menggambarkan hubungan antarlokasi berdasarkan persinggungan antarsisi dari peta tematik. Bentuk umum Matriks Pembobot Spasial yaitu:

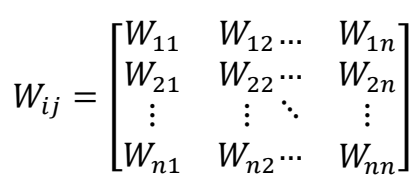

Nilai $W_{i j}$ akan bernilai 0 apabila $i$ dan $j$ tidak saling bersisian dan apabila $i$ dan $j$ saling bersisian maka $W_{i j}$ akan bernilai 1 .

c. Menyelidiki ada tidaknya autokorelasi antardusun dengan melakukan Uji Moran's I. Hipotesis dari Uji Moran's I yaitu:

$H_{0}: I=0$ (tidak ada autokorelasi
antardusun) $H_{1}: I \neq 0$ (ada autokorelasi antardusun) Dengan statistik Uji Moran's I (Anselin, 1988) yaitu:

$$
\begin{gathered}
Z_{\text {hitung }}=\frac{I-E(I)}{V(I)^{1 / 2}} \\
I_{0}=-\frac{1}{N-1}
\end{gathered}
$$

Jika $I>I_{0}$, hal tersebut mengindikasikan bahwa terdapat autokorelasi positif antardusun, sedangkan jika $I<I_{0}$ berarti terdapat autokorelasi yang negatif antardusun. Kriteria keputusan dalam pengambilan kesimpulan adalah menolak $H_{0}$ jika $Z_{\text {hitung }}>Z_{\alpha / 2}$

d. Menyelidiki ada tidaknya kebergantungan spasial pada lag dengan menggunakan Uji Lagrange Multiplier (LM). Hipotesis dari uji LM adalah:

$H_{0}: \rho=0$ (tidak terdapat kebergantungan spasial pada lag)

$H_{0}: \rho \neq 0$ (terdapat kebergantungan spasial pada lag)

Statistik Uji LM (Anselin, 1988) yaitu:

$$
L M=\frac{\left(e^{\prime} W y / \hat{\sigma}^{2}\right)^{2}}{D+T} \sim \chi^{2}(1)
$$

Kriteria keputusan dalam pengambilan kesimpulan adalah menolak $\mathrm{H}_{0}$ jika $L M>\chi^{2}(1)$.

e. Menyelidiki ada tidaknya keragaman antardusun dengan Uji Breusch-Pagan. Hipotesis dari Uji Breusch-Pagan yaitu:

$H_{0}: \sigma_{1}{ }^{2}={\sigma_{2}}^{2}={\sigma_{3}}^{2}=\cdots=\sigma_{n}{ }^{2}=\sigma^{2}$ 
$H_{1}$ : minimal terdapat satu ${\sigma_{i}}^{2} \neq \sigma^{2}$

Statistik Uji Breusch-Pagan (Anselin, 1988) yaitu:

$$
B P=\frac{1}{2} f^{\prime} Z\left(Z^{\prime} Z\right)^{-1} Z^{\prime} f \sim \chi^{2}
$$

Kriteria keputusan dalam pengambilan kesimpulan adalah menolak $\mathrm{H}_{0}$ jika $B P>$ $\chi^{2}(p)$.

Apabila dalam pengujian tersebut, diketahui terdapat efek spasial, maka dilanjutkan pada pemodelan SAR dengan melakukan pengujian signifikansi parameter dengan Uji Wald dan memilih model terbaik berdasarkan kriteria nilai AIC terkecil dengan $\mathrm{R}^{2}$ terbesar.

Hipotesis dari uji Wald (Anselin, 1988) yaitu:

$$
\begin{aligned}
& \mathrm{H}_{0}: \rho, \beta_{j}=0 \text { (parameter tidak signifikan) } \\
& \mathrm{H}_{1}: \rho, \beta_{j} \neq 0 \text { (parameter signifikan) }
\end{aligned}
$$

Statistik uji Wald yaitu:

$$
\mathrm{W}=\left[\frac{\widehat{\beta}_{j}^{2}}{\operatorname{var}\left(\widehat{\beta}_{j}\right)}\right] \sim \chi_{\alpha, 1}^{2}
$$

Adapun kriteria keputusan dalam pengambilan kesimpulan adalah menolak $\mathrm{H}_{0}$ jika $\mathrm{W}>\chi_{\alpha, 1}^{2}$. Dalam penelitian ini, software yang digunakan yaitu ArcView GIS 3.3 dan OpenGeoda.



Gambar 1. Peta Tematik Kecamatan Blahbatuh

\section{HASIL DAN PEMBAHASAN}

\section{A. Gambaran Umum Kecamatan Blahbatuh}

Kecamatan Blahbatuh terdiri dari sembilan desa dan 67 dusun. Desa-desa tersebut antara lain Blahbatuh, Buruan, Bedulu, Saba, Pering, Keramas, Bona, Medahan, dan Desa Belega.
Berdasarkan data BPS Kabupaten Gianyar Tahun 2011, Kecamatan Blahbatuh memiliki 14.427 KK dan pada tahun 2016 sebesar 35,62\% KK masih menggunakan air sungai sebagai kebutuhan dalam menjalani aktivitasnya.

Berikut merupakan deskripsi beserta peta penyebaran dari masing-masing variabel. Warna 
pada peta yang semakin gelap mengindikasikan nilai amatan yang semakin tinggi, sedangkan warna yang semakin terang mengindikasikan nilai amatan yang semakin rendah pada dusun.

\subsection{Jumlah KK yang Berperilaku MCK di sungai}

Gambar 2 menunjukkan bahwa kategori sangat rendah untuk masyarakat yang berperilaku MCK di sungai yang berkisar pada skala (0-8) KK terjadi pada dusun-dusun berikut yaitu: Pekandelan, Taman, Tengah (Bedulu), Margasengkala, Goa, Batulumbang, Charmatiaga, Babakan, Satria, Selat, Kebon Kaja, Jasri, Belega Kangin, Kebon Kelod, Pasdalem, Prajamukti, Bona Kelod, Pasdalem, Bona Kelod, Dana, Pasedana, Gelgel, Pinda, Patolan, dan Sema (Saba).

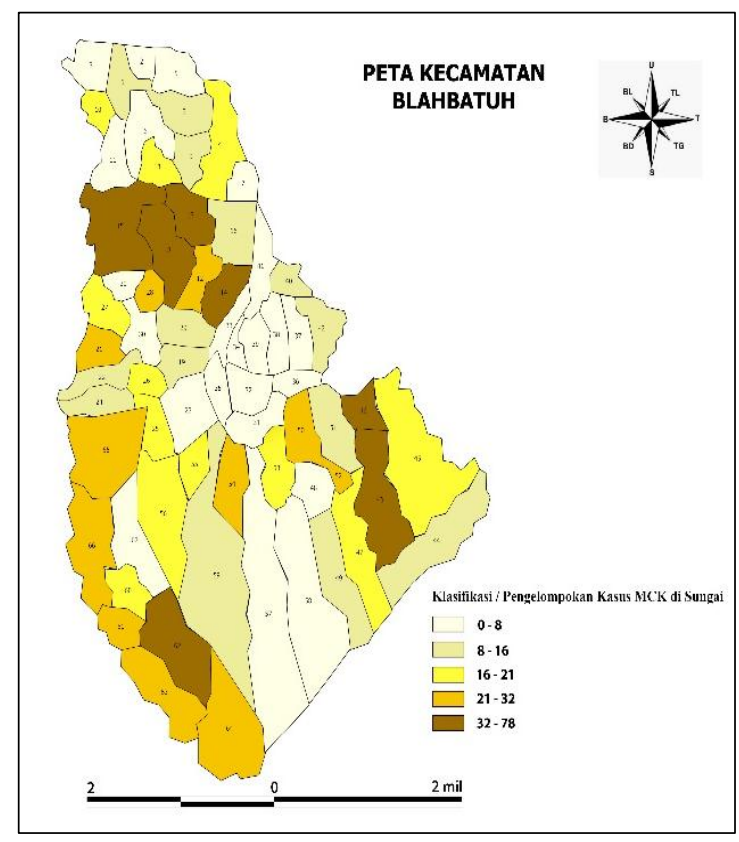

Gambar 2. Peta Penyebaran KK yang MCK di Sungai di Kecamatan Blahbatuh Tahun 2016

Sedangkan, kategori sangat tinggi untuk masyarakatnya berperilaku MCK di sungai yang berkisar pada skala (32-78) KK terjadi pada dusun-dusun berikut, yaitu Getas Kangin, Bangunliman, Kutri, Buruan, Anggarkasih, Penulisan, dan Banda.

\subsection{Jumlah KK Miskin}

Gambar 3 menunjukkan bahwa kategori sangat rendah jumlah KK miskin berkisar pada skala (0-12) KK terjadi pada dusun-dusun berikut, yaitu Ketandan, Dharmatiaga, Selat, Cucukan, dan Kawan. Sedangkan dusun-dusun yang termasuk dalam kategori sangat tinggi untuk jumlah KK miskin di Kecamatan Blahbatuh yang berkisar pada skala (56-95) KK di antaranya Margasengkala, Bangunliman, Buruan, Kerthiyasa, Anggarkasih, Penulisan, Biya, Palak, dan Banda.

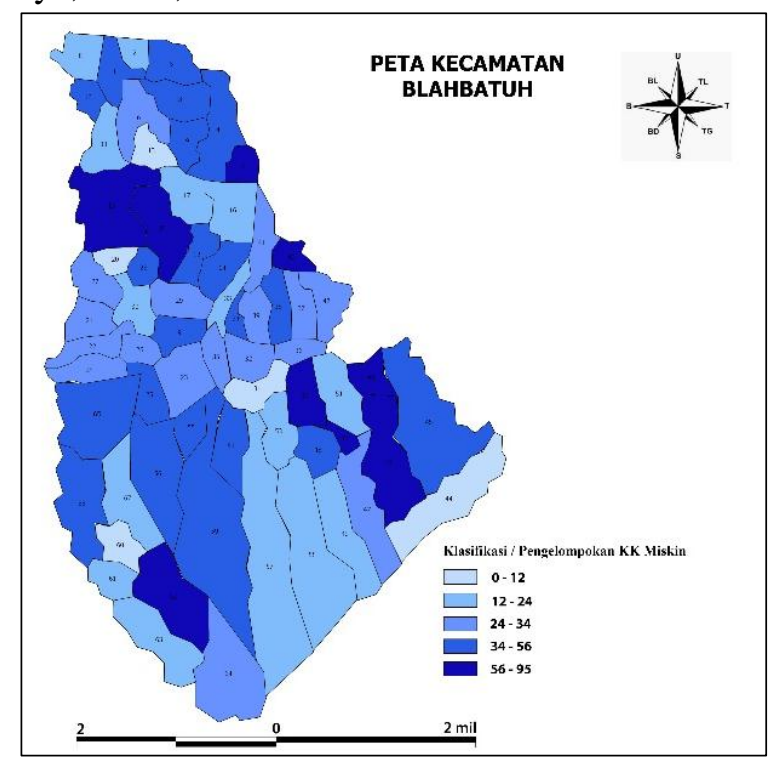

Gambar 3. Peta Penyebaran Jumlah KK Miskin di Kecamatan Blahbatuh Tahun 2016

\subsection{Jumlah KK yang Belum Memiliki} Jamban

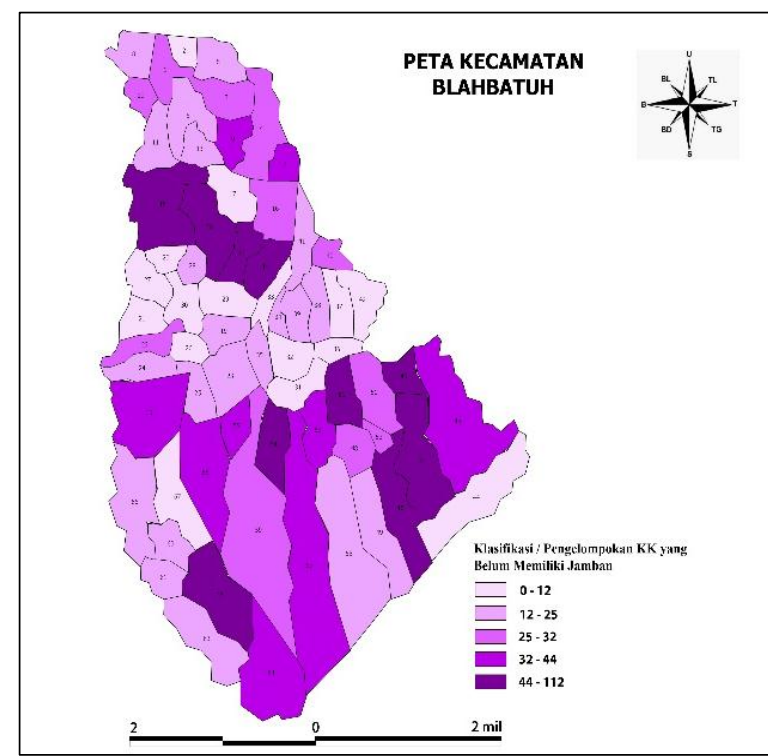

Gambar 4. Peta Penyebaran Jumlah KK yang Belum Memiliki Jamban di Kecamatan Blahbatuh Tahun 2016 
Gambar 4 menunjukkan bahwa kategori sangat rendah untuk jumlah KK yang belum memiliki jamban berkisar pada skala (0-12) KK terjadi pada dusun-dusun berikut, yaitu Pekandelan, Kutri, Dharmatiaga, Teruna, Kebon (Blahbatuh), Pokas, Tubuh, Satria, Selat, Kebon Kaja, Jasri, Pasdalem, Prajamukti, Kebon (Bona), Cucukan, dan Sema (Saba). Sedangkan, dusun-dusun yang termasuk dalam kategori sangat tinggi untuk jumlah $\mathrm{KK}$ yang belum meiliki jamban yang berkisar pada skala (44112) KK di antaranya Getas Kawan, Bangunliman, Buruan, Anggarkasih, Penulisan, Gelgel, Biya, Pering, Palak, dan Banda.

\subsection{Jumlah KK yang Tinggal Dekat Sungai}

Gambar 5 menunjukkan bahwa kategori sangat rendah untuk jumlah KK yang tinggal dekat sungai di Kecamatan Blahbatuh berkisar pada skala (0-5) KK terjadi pada dusun-dusun berikut, yaitu Pekandelan, Tengah (Bedulu), Goa, Tubuh, Tengah (Blahbatuh), Satria, Selat, Kebon Kaja, Jasri, Belega Kangin, Kebon Kelod, Pasdalem, Prajamukti, Dana, Gelgel, Pinda (Pering), Patolan, dan Sema (Saba).

Sedangkan, dusun-dusun yang termasuk dalam kategori sangat tinggi untuk KK yang tinggal dekat sungai yang berkisar pada skala (35-75) KK di antaranya Getas Kawan, Bangunliman, Kutri, Buruan, Anggarkasih, Penulisan, dan Banda.

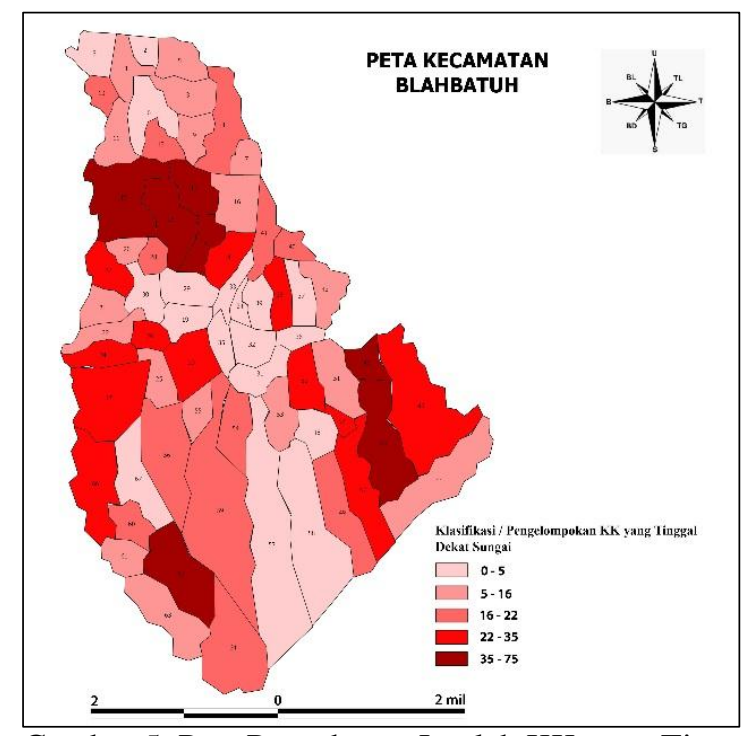

Gambar 5. Peta Penyebaran Jumlah KK yang Tinggal Dekat Sungai di Kecamatan Blahbatuh Tahun 2016

\subsection{Jarak Pemukiman Warga dengan Sungai}

Gambar 6 menunjukkan bahwa kategori jarak paling dekat antara pemukiman warga dengan sungai yang berkisar pada skala $(0-5)$ meter terdapat pada dusun-dusun berikut, yaitu Tengah (Bedulu), Goa, Getas Kawan, Ketandan, Getas Kangin, Bangunliman, Kutri, Antugan, Selat, Kebon Kaja, Jasri, Belega Kangin, Kebon Kelod, Pasdalem, Prajamukti, Dana, Gelgel, Pinda (Pering), dan Patolan. Sedangkan kategori jarak paling jauh antara pemukiman warga sungai yang berkisar pada skala $(60-100)$ meter terdapat pada dusun-dusun berikut, yaitu Mas, Celuk, Tusan, Satria, Pasedana, Cucukan, dan Lebah.

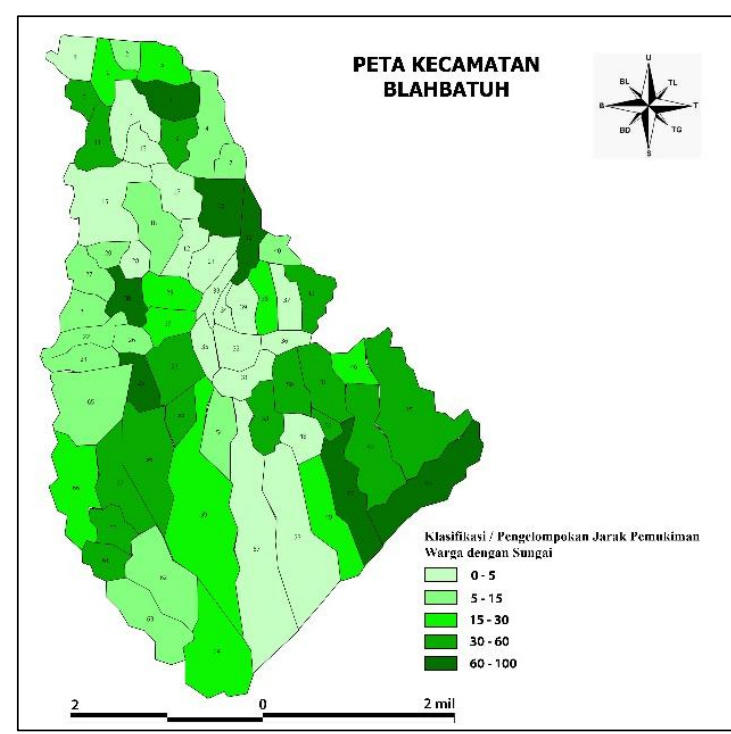

Gambar 6. Peta Penyebaran Jarak Pemukiman Warga dengan Sungai di Kecamatan Blahbatuh Tahun 2016

\section{B. Pengujian Efek Spasial}

Efek spasial dapat diselidiki dengan melakukan Uji Moran's I, Uji Lagrange Multiplier (LM), dan Uji Breusch-Pagan.

Tabel 1. Uji Autokorelasi dengan Uji Moran's I

\begin{tabular}{|c|c|c|}
\hline Variabel & Moran's I & $Z_{\text {hitung }}$ \\
\hline $\mathrm{Y}$ & 0,29874 & $3,2007^{*}$ \\
\hline $\mathrm{X}_{1}$ & 0,16726 & $-2,6351^{*}$ \\
\hline $\mathrm{X}_{2}$ & 0,08741 & $5,9418^{*}$ \\
\hline $\mathrm{X}_{3}$ & 0,24888 & $4,8953^{*}$ \\
\hline $\mathrm{X}_{4}$ & 0,13926 & $-2,0493^{*}$ \\
\hline$I_{0}=-0,0151$ & \multicolumn{2}{|l}{} \\
\hline$\alpha=0,05$ & $\mathrm{Z}_{0,025}=1,96$ \\
\hline
\end{tabular}

Sumber: Data Diolah Tahun 2017 
Tabel 1 menunjukkan bahwa nilai $\left|z_{\text {hitung }}\right|$ semua variabel lebih besar dari nilai $z_{\text {tabel }}$, sehingga keputusan yang diambil adalah menolak $\mathrm{H}_{0 .}$, yang mengindikasikan bahwa variabel $\mathrm{y}, \mathrm{X}_{1}, \mathrm{X}_{2}, \mathrm{X}_{3}$, dan $\mathrm{X}_{4}$ signifikan. Hal ini berarti terdapat autokorelasi antardusun untuk jumlah KK yang berperilaku MCK di sungai (y), jumlah KK miskin $\left(\mathrm{X}_{1}\right)$, jumlah KK yang belum memiliki jamban $\left(\mathrm{X}_{2}\right)$, jumlah KK yang tinggal dekat sungai $\left(\mathrm{X}_{3}\right)$, dan jarak pemukiman warga dengan sungai di Kecamatan Blahbatuh $\left(\mathrm{X}_{4}\right)$.

Tabel 2. Uji Kebergantungan Spasial

\begin{tabular}{|l|c|c|}
\hline \multicolumn{1}{|c|}{ Uji Kebegantungan Spasial } & Nilai & Prob. \\
\hline Lagrange Multiplier (lag) & 6,9453 & 0,0349 \\
\hline Lagrange Multiplier (error) & 4,8094 & 0,0715 \\
\hline$\alpha=0,05$ & \\
\hline
\end{tabular}

Sumber: Data Diolah Tahun 2017

Uji kebergantungan spasial menunjukkan bahwa probabilitas atau $p$-value dari LM (lag) yaitu $0,0349<0,05$ sehingga keputusan yang diambil adalah menolak $\mathrm{H}_{0}$ yang berarti terdapat kebergantungan spasial antardusun, dan model yang sesuai untuk digunakan adalah SAR.

Tabel 3. Uji Heterogenitas Spasial

\begin{tabular}{|l|l|l|l|}
\hline \multicolumn{1}{|c|}{ Uji } & DF & Nilai & Prob. \\
\hline Breusch-Pagan Test & 4 & 6,8845 & 0,0097 \\
\hline$\alpha=0,05$ &
\end{tabular}

Sumber: Data Diolah Tahun 2017

Uji keragaman spasial menunjukkan bahwa probabilitas atau $p$-value dari Uji LM $0,0097<0,005$ sehingga keputusan yang diambil adalah menolak $H_{0}$ yang berarti terdapat keragaman spasial antardusun. Hal ini mengindikasikan bahwa dusun di Kecamatan Blahbatuh saling memengaruhi untuk kasus MCK di sungai. Karena terdapat efek spasial pada kasus masyarakat yang berperilaku MCK di sungai di Kecamatan Blahbatuh, maka dilakukan pemodelan spasial yaitu SAR.

\section{Pemodelan SAR}

Pada SAR, pemodelan dilakukan dengan menguji signifikansi parameter terlebih dulu.
Tabel 4. Pendugaan Parameter dengan Uji Wald

\begin{tabular}{|c|c|c|c|}
\hline Parameter & Estimasi & Std. Error & Wald \\
\hline$\rho$ & 0,4857 & 0,2399 & $11,9134^{*}$ \\
\hline$\beta_{0}$ & 11,128 & 1,1966 & 0,0564 \\
\hline$\beta_{1}$ & 2,0824 & 0,2047 & $3,9121^{*}$ \\
\hline$\beta_{2}$ & 3,5451 & 0,5978 & $4,5983^{*}$ \\
\hline$\beta_{3}$ & $-3,6927$ & 0,0025 & $3,0008^{*}$ \\
\hline$\beta_{4}$ & $-2,0308$ & 0,9882 & 2,4842 \\
\hline$\chi_{0,1: 1}^{2}=2,706$ \\
\hline$\alpha=0,1$
\end{tabular}

Tabel 4 menunjukkan bahwa terdapat parameter dengan nilai Wald yang lebih besar dari pada 2,706 sehingga keputusan yang diambil adalah menolak $\mathrm{H}_{0}$. Hal ini berarti parameter yang digunakan signifikan, yang ditunjukkan oleh parameter $\rho$, sedangkan pada variabel bebas ditunjukkan oleh jumlah KK Miskin $\left(\mathrm{X}_{1}\right)$, jumlah KK yang belum memiliki jamban $\left(\mathrm{X}_{2}\right)$ dan jumlah KK yang tinggal dekat sungai $\left(\mathrm{X}_{3}\right)$.

Berdasarkan Tabel 4, diperoleh model dugaan SAR untuk semua variabel bebas yaitu:

$$
\begin{aligned}
\hat{y}_{i}= & 11,128+0,4857 \sum_{j=1, i \neq j}^{n} w_{i j} y_{j}+2,0824 X_{1 i} \\
& +3,5451 X_{2 i}-3,6927 X_{3 i}-2,0308 X_{4 i}
\end{aligned}
$$

\section{Pemilihan Model Terbaik}

Model SAR yang diperoleh dengan beberapa kombinasi variabel, selanjutnya dilakukan pemilihan model terbaik berdasarkan nilai AIC terkecil.

Tabel 5. Nilai AIC dan $\mathrm{R}^{2}$

\begin{tabular}{|c|c|c|}
\hline Variabel & $\mathrm{AIC}$ & $\mathrm{R}^{2}$ \\
\hline $\mathrm{X}_{1}$ & 158,48 & 0,428 \\
\hline $\mathrm{X}_{2}$ & 161,66 & 0,639 \\
\hline $\mathrm{X}_{3}$ & 168,37 & 0,790 \\
\hline $\mathrm{X}_{4}$ & 156,20 & 0,426 \\
\hline $\mathrm{X}_{1}, \mathrm{X}_{2}$ & 170,01 & 0,643 \\
\hline $\mathrm{X}_{1}, \mathrm{X}_{3}$ & 152,12 & 0,689 \\
\hline $\mathrm{X}_{1}, \mathrm{X}_{4}$ & 166,20 & 0,440 \\
\hline $\mathrm{X}_{\mathbf{2}}, \mathrm{X}_{\mathbf{3}}$ & $\mathbf{1 4 6 , 2 1}$ & $\mathbf{0 , 8 5 0}$ \\
\hline $\mathrm{X}_{2}, \mathrm{X}_{4}$ & 163,30 & 0,603 \\
\hline $\mathrm{X}_{3}, \mathrm{X}_{4}$ & 167,27 & 0,692 \\
\hline $\mathrm{X}_{1}, \mathrm{X}_{2}, \mathrm{X}_{3}$ & 153,19 & 0,854 \\
\hline $\mathrm{X}_{1}, \mathrm{X}_{2}, \mathrm{X}_{4}$ & 171,33 & 0,644 \\
\hline $\mathrm{X}_{1}, \mathrm{X}_{3}, \mathrm{X}_{4}$ & 160,57 & 0,684 \\
\hline $\mathrm{X}_{2}, \mathrm{X}_{3}, \mathrm{X}_{4}$ & 163,58 & 0,731 \\
\hline $\mathrm{X}_{1}, \mathrm{X}_{2}, \mathrm{X}_{3}, \mathrm{X}_{4}$ & 168,71 & 0,828 \\
\hline
\end{tabular}

Sumber: Data Diolah Tahun 2017 
Tabel 5 menunjukkan bahwa nilai AIC paling kecil yaitu 146,21 dengan $\mathrm{R}^{2}$ sebesar 85 $\%$ terdapat pada model ke- 8 . Hal tersebut berarti sebesar $85 \%$ jumlah KK yang belum memiliki jamban $\left(\mathrm{X}_{2}\right)$ dan jumlah KK yang tinggal dekat sungai $\left(\mathrm{X}_{3}\right)$ mampu menjelaskan kasus masyarakat yang berperilaku MCK di sungai di Kecamatan Blahbatuh pada Tahun 2016, sedangkan sebesar $15 \%$ dijelaskan oleh variabel lain di luar model.

Tabel 6 mengenai pendugaan parameter menunjukkan bahwa semua nilai Wald lebih besar dari 2,706 sehingga keputusan yang diambil adalah menolak $\mathrm{H}_{0}$ yang berarti semua parameter signifikan.

Tabel 6. Pendugaan Parameter Model Terbaik

\begin{tabular}{|c|c|c|c|}
\hline Parameter & Estimasi & $\begin{array}{l}\text { Std. } \\
\text { Error }\end{array}$ & Wald \\
\hline$\rho$ & 0,4372 & 0,2673 & $17,2418^{*}$ \\
\hline$\beta_{0}$ & 12,1790 & 0,1332 & $2,9201^{*}$ \\
\hline$\beta_{2}$ & 0,2443 & 0,0556 & $4,7765^{*}$ \\
\hline$\beta_{3}$ & 0,6748 & 0,0709 & $6,8194^{*}$ \\
\hline$\chi_{0,1: 1}^{2}=2,706$ & \\
\hline$\alpha=0,10$ &
\end{tabular}

Sumber: Data diolah tahun 2017

Berdasarkan tabel 6, diperoleh model SAR terbaik yaitu:

$$
\begin{gathered}
\widehat{y}_{l}=12,179+0,4372 \sum_{j=1, i \neq j}^{n} w_{i j} y_{j}+ \\
0,2443 X_{2 i}+0,6748 X_{3 i}
\end{gathered}
$$

Koefisien $\rho$ pada model SAR yaitu 0,4372 menginterpretasikan bahwa masyarakat yang berperilaku MCK di sungai di Kecamatan Blahbatuh dipengaruhi oleh dusun yang mengelilinya sebesar 0,4372 kali. Koefisien $\beta_{0}$ sebesar 12,179 menginterpretasikan bahwa jika semua KK memiliki jamban dan tidak ada KK yang tinggal dekat sungai, maka rata-rata $\mathrm{KK}$ yang berperilaku MCK di sungai di Kecamatan Blahbatuh pada Tahun 2016 sekitar 13 KK. Koefisien $\beta_{2}$ sebesar 0,2443 berarti jika KK yang belum memiliki jamban di suatu dusun naik sekitar sepuluh KK, maka akan menaikkan jumlah masyarakat (KK) yang berperilaku MCK di sungai sekitar $2 \mathrm{KK}$, jika dan hanya jika faktor lain dianggap konstan, sedangkan $\begin{array}{llll}\text { koefisien } & \beta_{3} & \text { sebesar } & 0,6478\end{array}$ menginterpretasikan bahwa jika jumlah KK yang tinggal dekat sungai di suatu dusun naik sekitar $10 \mathrm{KK}$, maka akan menaikkan jumlah masyarakat (KK) yang berperilaku MCK di sungai sekitar $6 \mathrm{KK}$, jika dan hanya jika faktor lain dianggap konstan. Model SAR juga menunjukkan bahwa masing-masing dusun memiliki model SAR yang berbeda tergantung pada matriks pembobot spasialnya. Sebagai contoh model SAR untuk Dusun Margabingung yaitu:

$$
\begin{aligned}
\hat{y}_{\text {Margabingung }}= & 12,1790+0,3472 y_{\text {Pekandelan }} \\
& +0,3472 y_{\text {Mas }}+0,3472 y_{\text {Taman }} \\
& +0,3472 y_{\text {Tengah_Bedulu }} \\
& +0,3472 y_{\text {Goa }} \\
& +0,3472 y_{\text {Batulumbang }} \\
& +0,2443 X_{2 \text { Margabingung }} \\
& +0,6748 X_{3 \text { Margabingung }}
\end{aligned}
$$

\section{KESIMPULAN DAN SARAN}

\subsection{Kesimpulan}

Model SAR terbaik berdasarkan nilai AIC terkecil yaitu 146,214 dengan nilai $\mathrm{R}^{2}$ sebesar $85,05 \%$ yang dapat digunakan untuk menjelaskan masyarakat yang berperilaku MCK di sungai, di Kecamatan Blahbatuh pada tahun 2016 yaitu:

$$
\begin{gathered}
\widehat{y_{l}}=12,179+0,4372 \sum_{j=1, i \neq j}^{n} w_{i j} y_{j}+0,2443 X_{2 i} \\
+0,6748 X_{3 i}
\end{gathered}
$$

dan diperoleh pula faktor-faktor yang memengaruhi masyarakat berperilaku MCK di sungai di Kecamatan Blahbatuh pada tahun 2016 adalah jumlah KK tiap dusun yang belum memiliki jamban dan jumlah KK tiap dusun yang tinggal dekat di sungai di Kecamatan Blahbatuh.

\subsection{Saran}

Saran yang peneliti berikan dari penelitian ini yaitu Pemerintah Kecamatan Blahbatuh sebaiknya memberikan bantuan pembuatan jamban atau kamar mandi kepada masyarakat yang tegolong kurang mampu, walaupun sungai yang ada di dusun-dusun di Kecamatan Blahbatuh tersebut masih terlihat bersih. 


\section{DAFTAR PUSTAKA}

Anselin, L., 1988. Spatial Econometrics : Method and Models. The Netherlands: Kluwer Academic Publisher.

Fachrudin, H. T. \& Dolok, L. M., 2016. Planning for Riverside Area as Water Tourism Destination to Improve Quality of Life Local Residents, Case Study: BatuanSikambing River, Medan, Indonesia. Procedia -Social and Behavioral Sciences, 234(2016), pp. 434-441.

LeSage, J. P., 1999. The Theory and Practice of Spatial Econometrics. University of Toledo: Department of Economics.

Neter, J., Wasserman, W. \& Kutner, M. H., 1983. Applied Linear Regression. Illnois: Richard D. Irwin.
Qudsiyah, W. A., Sri, P. R. \& Ningrum, P. T., 2015. Faktor-Faktor yang Berhubungan dengan Tingginya Angka Open Defecation (OD) di Kabupaten Jember (Studi di Desa Sumber Kalong Kecamatan Kalisat). $e$ Jurnal Pustaka Kesehatan, 3 (2), p. 8.

Sasongko, L. A., 2011. Perilaku Hidup Klaster Masyarakat Di Sekitar Sungai Tuk Terhadap Air Limbah Domestik. Jurnal Ilmu-ilmu Pertanian, 1(10), pp. 10-25. 